\title{
The Effect of Public Education on Improving the Economy Through Tourism Spot in Gili Genting Island
}

\author{
Rini Yudiati* \\ Medical Department \\ University Wiraraja \\ Sumenep, Indonesia \\ *riniyudiatisusilo@gmail.com
}

\author{
Syahril Syahril \\ Economic and Business Department \\ University Wiraraja \\ Sumenep, Indonesia \\ syahri149@yahoo.co.id
}

\begin{abstract}
Public education in improving the economy requires support from various parties, which of course will greatly influence the welfare of Gili Genting Island has known as Pantai Sembilan Tourism which has assets that can be shown to all Indonesian and international communities. This research aimed to analyse the effect of public education on improving the economic through tourism spots in Gili Genting Island. The population which has taken in this research is Gili Genting community with 100 samples. The method used is proportional random sampling. Data collection is done by questionnaire and it is analyzed by using path analysis. The result showed that (1) there are significant effects between public education on improving economic; (2) there are significant effects between tourism spot on improving the economic; (3) there are significant direct effects between public educations on improving the economic; (4) and there are significant direct effect between public educations on improving economic through tourism spots. The conclusion is that improving the economy in the Gili Genting Island depends on the education of community, especially the youth in developing tourism spots in Gili Genting island.
\end{abstract}

Keywords: public education, improving economic, tourism spot

\section{INTRODUCTION}

Success factor of regional economic development is the occurrence of improving economic and an increase in the income of a region's people. Economic development cannot be separated from economic growth, where economic development encourages economic growth and vice versa economic growth facilitates the economic development of a country or region. Economic growth is a process where an increase in gross national product or real national income. In this case economic growth is needed in order to improve the standard of living and welfare of the community in general. High economic growth in the era of regional autonomy is also one of the economic goals of a region. Many factors affect the economic growth of a region one of the factors that influence economic growth is human resources (education). The education sector has an important role in shaping the ability of a developing country to absorb modern technology and develop production capacity to create sustainable growth and development.
Abundant natural resources are not necessarily a guarantee that a country or region will prosper if the education of its human resources receives less attention. Efforts to improve the quality of human resources is a joint task and a long period of time because it involves the nation's education. The community is the main actor for development, it requires the quality of potential human resources, so that the community can move towards development towards the aspirations of the people of Indonesia, namely a prosperous nation and noble personality, especially in facing the 4.0 era which is required to more advanced and broad minded. People are required to have the skills or competencies so that they become human beings that are useful for themselves, for the nation and the State, to explore the potential possessed by humans, education is needed.

Human resources are the capital of a nation to improve the quality of human beings where human beings are active production factors in collecting capital, building social, economic, political organizations, and implementing national development [1]. These efforts can be done through education. In education an individual will be given knowledge, skills, and the inculcation of national character values that are integrated in a subject.

Gili Genting is one of the 126 islands in Sumenep Regency. This island has 4 villages namely Aeng Anyar, Galis, Geddugan, and Bringsang. Bringsang is one of four villages that have tourist attractions, namely "Pantai Sembilan". This tourist spot is a new tourist attraction in Sumenep which is still under development. The development of "Pantai Sembilan" tourism is certainly very appropriate with the Sumenep district government program namely visit Sumenep. According to Law no. 6 of 2014 concerning villages, that villages were given the freedom to manage their villages in order to contribute to the village itself and also the local area. However, socioeconomic does not stand alone but has a dependency and interrelationship in the political field of social education or family and religion in this case educational activities specifically framed that can affect the socioeconomic life of the people on the island. 
Indonesian people, especially in the Sumenep area believe that someone who has a formal education provision tends to be successful in the economic field, the assumption does not appear by itself, but based on the reality, for example, in the era of the New Order, most jobs now require workers who have a background or background. formal education can be absorbed in various fields of work. Since then the community's perception of education shifting schools / educational institutions is considered as a strategy force to achieve life progress without a case through other economic media which are slower and have a high risk of experiencing failure.

The village development carried out on the island of Gili Genting greatly influenced several existing sectors such as the economy and education. Education also plays an important role in the process of village development. Reported in the RadarMadura.id IPM news in the city of Sumekar Experiencing Positive Trends. Since the last two years, the school's old school expectation index in 2016 has been at 12.73 years while in 2017 it has risen to 12.74 . The literacy rate in Sumenep district in 2017 was $93.98 \%$, previously at $79.34 \%$. This shows that there is a significant increase. So, that means that education in Sumenep successfully embraces the community [2].

Tourism is one type of industry that is able to promote fast and reliable economic growth, by providing employment, increasing income and living standards, and stimulating other productivity sectors such as; handicrafts and souvenirs, lodging and transportation. Tourism as one of the development sectors and the driving force of the economy cannot be separated from its relation to sustainable development that has been declared by the government in accordance with national development goals. Sustainable tourism development is development that can be supported ecologically as well as economically feasible, also ethically and socially fair to the community. Sumenep Regency began to develop natural resources that have the potential to become tourist destinations, one of which is beach tourism in Giligenting District, namely Sembilan Beach tourism, this tour was opened to the public in January 2016, the purpose of this tourism development is to improve the economy of the local community, in sustainable development that is considered not only the economic dimension, but also the very important ecological and social dimensions.

Previous research compiled by Nugroho SBM, states that Education in Proxies with Literacy Rates has a positive and significant effect on diproxy economic growth with Gross Domestic Product [3]. This research journal is intended to follow up on research that has been conducted by Nugroho [3], this is because researchers have an interest in reresearching by including other factors that affect economic improvement by adding the $\mathrm{Y}$ variable, namely the tourism spot.

Research from Foster and Rosenzweig [4] on the impact of education on farmers in India during the green revolution can give a little picture. Studies on the agricultural sector in India (including Indonesia) are very relevant in the discourse of economic development because the majority of the population, included in the poorest groups, are in this sector. In the study farmers who have basic education are far more productive than those who have never attended school. Although, there is no significant difference between those who have secondary education and those who only have basic education.

Areas with poor natural and geographical conditions, often productivity is determined by experience, not education. For farmers who are in places like this, going to school besides not providing much benefit, also makes them lose many years of experience working in the fields. People able to argue back, that people with education able to social mobility experience. They must not continue to be farmers and poor people if they can get an education. That is the problem. In many other developing countries, social mobility is not always possible. In India, caste is one of the barriers to social mobility, in addition to many other obstacles. In a country like Indonesia, where corruption is rooted to the level of recruitment, it can be another reason why social mobility is still relatively difficult to occur.

Based on the background of the problems that have been described above then hypothesized as follows:

H1: There is an effect of public education on tourism spots

$\mathrm{H} 2$ : There is a direct effect of public education on improving the economy

H3: There is an effect of tourism spots on improving the economy

H4: There is an indirect effect of community education on Improving the economy through the tourism spot

Relationship between independent and bound variables can be seen in the Figure below:

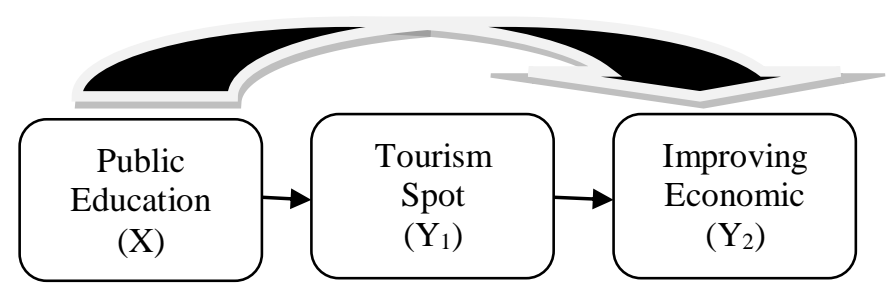

Fig. 1. The correlation of independent and bound variables.

\section{METHODS}

This research is categorized as explanatory research, namely research that aims to explain the casual relationship between variables through hypothesis testing. This research was conducted by explaining the symptoms that arise by an object. The population of this research is the Gili Genting community. Samples were taken from four villages of 100 people, so researcher took 25 people each village. Samples taken as many as 100 people already more than 42 or $25 \%$ of the total population will be able to produce representative data [5]. 
effect between public education on tourism spots was rejected and Ha stated that there was a direct effect between public

TABLE I. PROPORTION OF SAMPLE CALCULATION

\begin{tabular}{|l|l|l|}
\hline No & \multicolumn{1}{|c|}{ Village } & Total \\
\hline 1 & Aeng Anyar & 25 \\
2 & Galis & 25 \\
3 & Geddugan & 25 \\
4 & Bringsang & 25 \\
\hline Total & \multicolumn{2}{c|}{100} \\
\hline \multicolumn{2}{|c|}{ Source: (data processed) }
\end{tabular}

Measurement variables are developed from indicators that exist in the variable description, used as question item. Then the questions are adjusted according to variables through a questionnaire or questionnaire to get primary data. While the documentation includes secondary data to supplement primary data, namely on improving the economy.

Collecting data on public education and tourism spots used questionnaires about the state of education in the islands and tourism spots in the Gili Genting islands. The method of scoring the answers to each question item for respondents has a value in the following table:

TABLE II. THE WEIGHT OF THE QUESTION ITEM SCORE

\begin{tabular}{|l|l|}
\hline \multicolumn{1}{|c|}{ Item } & Weight \\
\hline Answer A & 5 \\
Answer B & 4 \\
Answer C & 3 \\
Answer D & 2 \\
Answer E & 1 \\
\hline
\end{tabular}

The description of variables and indicators that are used as a reference for making question items as bellow:

TABLE III. DESCRIPTION OF VARIABLES

\begin{tabular}{|c|c|c|}
\hline Variable & Sub Variable & Indicator \\
\hline $\begin{array}{l}\text { Independent } \\
\text { variable: } \\
\text { Public Education } \\
\text { (X) }\end{array}$ & $\begin{array}{l}\text { Public } \\
\text { Education }\end{array}$ & $\begin{array}{l}\text { - Level of education on Gili } \\
\text { Genting } \\
-\quad \text { Level of Education } \\
\text { Understanding on Gili Genting }\end{array}$ \\
\hline $\begin{array}{l}\text { Bound variable: } \\
\text { Tourism Spot } \\
\left(\mathrm{Y}_{1}\right)\end{array}$ & $\begin{array}{l}\text { Tourism Spot in } \\
\text { Gili Genting }\end{array}$ & $\begin{array}{l}\text { - The improving of Tourism } \\
\text { Spot in Gili Genting } \\
-\quad \text { Maintenance of Tourism } \\
\text { Spot in Gili is critical }\end{array}$ \\
\hline $\begin{array}{l}\text { Bound variable: } \\
\text { Improving } \\
\text { Economic } \\
\left(\mathrm{Y}_{2}\right)\end{array}$ & $\begin{array}{l}\text { The Improving } \\
\text { economic in Gili } \\
\text { Genting }\end{array}$ & $\begin{array}{l}\text { The level of understanding of } \\
\text { entrepreneurship on the island } \\
\text { of Gili Genting }\end{array}$ \\
\hline
\end{tabular}

\section{RESULTS}

Based on the results of descriptive statistical analysis data on Public education, an average value of 19.52 with a standard deviation of 4.69 is obtained. This value provides a general picture that the average public education is quite low.

The results of data analysis using a significance level of $5 \%$ showed that the direct effect between public education (X) on tourism spots $(\mathrm{Y} 1)$ was obtained $\mathrm{t}_{\text {count }}=5.963$ with $\mathrm{t}_{\text {table }}=$ 1.984. So $t_{\text {count }}>t_{\text {table }}$, so Ho who stated there was no direct education on tourism spots (Y1) being accepted. The coefficient (R2) is equal to 0.266 which means that $26.6 \%$ of the change in the tourism spot variable is caused by changes in public education while the remaining $73.4 \%$ is caused by other factors not contained in the equation. Standardized beta coefficient of 0.516 indicates that there is a rather low correlation between public education and tourism spots.

The results of descriptive statistical analysis of tourism spots obtained an average value of 18.01 with a standard deviation of 4.30. This value gives a general picture that the average tourism spot is less supportive. From the analysis of descriptive statistical data on improving the economy an average value of 74.57 is obtained with a standard deviation of 4.20. Based on the above distribution gives a general picture that the average increase in the economy is sufficient

The results of data analysis using a significance level of $5 \%$ showed that the direct influence between public education $(\mathrm{X})$ on improving economic (Y2) obtained $t_{\text {count }}=3.473$ with $t_{\text {table }}=1.984$. So $t_{\text {count }}>t_{\text {table }}$, so HO which states there is no direct effect between public education (X) on improving economic (Y2) is rejected and Ha which states there is a direct influence between public education (X) on improving economic (Y2) is accepted. While the coefficient (R2) is 0.108 , which means that $10.8 \%$ of the change in improving economic variables is caused by changes in public education while the remaining $89.2 \%$ is caused by other factors not contained in the equation. Standardized beta coefficient value of 0.328 indicates that there is a low correlation between public education (X) on improving economic (Y2).

The results of data analysis using a significance level of $5 \%$ showed that the direct effect between tourism spots (Y1) on improving economic (Y2) obtained $t_{\text {count }}=3.354$ with $t_{\text {table }}$ $=1.984$. so $t_{\text {count }}>t_{\text {table }}$, so $\mathrm{H} 0$ which states there is no direct effect between tourism spots (Y1) on improving economic (Y2) is rejected and Ha which states there is a direct influence between tourism spots (Y1) on improving economic (Y2) is accepted. While the coefficient (R2) is 0.103 , which means that $10.3 \%$ of the variable changes in improving economic economic are caused by changes in tourism spots while the remaining $89.7 \%$ is caused by other factors not contained in the equation. The standardized beta coefficient value of 0.321 indicates that there is a low correlation or relationship between tourism spots (Y1) and improving economic (Y2).

After knowing the direct effect of each independent variable on the assessment variables in the first and second equation models, then the indirect and total comparisons of the community decline variable $(\mathrm{X})$ are calculated on the investment increase (Y2) through the intervening spot tourism variable (Y1) [6]. To make it easier to first arrange the path analysis model as follows:

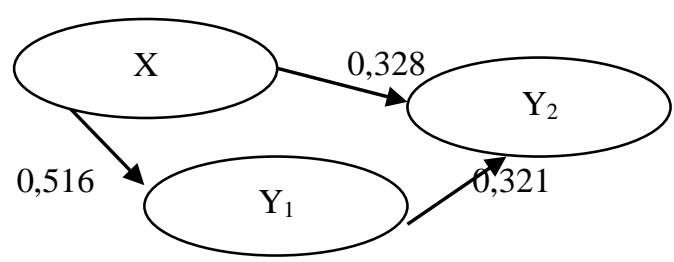


breath of fresh air for villages in Gili Genting especially in Bringsang village. They made tourism in Gili Genting more developed and became known by the national and international community. It could even become a favorite tourism destination in 2017. The Gili Genting community starts to send their children to a higher level so that the next generation of village youth can help the elders in the village in village development.

Hypothesis 2 which states that there is a positive and significant direct effect between public education on improving the economy is accepted. The direct influence between public education on improving economic of 0.328 with a significance level of 0,000 or a probability of less than 1 where this can be interpreted to have a significant effect. The state of community education can play a role in improving the economy because the level of public education is one of the keys to success in improving the economy of a group. Public awareness of education will improve their economic levels automatically.

In the $70 \mathrm{~s}$, there was a theory that emphasized that in

Based on the table above, it can be calculated the magnitude of the effect of all path variables either directly, indirectly or the total effect and can be recognized the level or high or low relationship between these variables through the beta coefficient value of the indirect effect of public education (X) on improving economic (Y2) through tourism spots (Y1), through multiplication of standardized beta coefficients between public education (X) with tourism spots (Y1) and tourism spots (Y1) with an economic increase (Y2) which is then added to the beta value of public education $(\mathrm{X})$ on improving economic (Y2).

The results of the standardized beta coefficient the indirect effect of public education on improving the economy through tourism spots by 0.166 is smaller than the effect of public education on improving the economy which has a value of 0.328 . The total beta coefficient value of 0.494 shows that there is a rather low indirect effect between public education on improving the economy through tourism spots.

\section{DISCUSSION}

Hypothesis 1 which states that there is a positive and significant direct effect between public education on tourism spots is accepted. The direct effect between public education on tourism spots is 0.516 with a significance level of 0.000 or a probability of less than 1 where this can be interpreted as having a significant general effect. Public education will affect the existence of tourism spots. This is caused by community education which is starting to change better from year to year. Education of a community determines the status or role in human life, economic status determines the ability in the development of villages in an area. The education of Gili Genting people is mostly elementary school graduates and works as fishermen and in general they have a relatively low income so that in improving the village economy is also less reliable.

The tourism spot "Pantai Sembilan" in the village of Bringsang can develop because the education of the people around it is better. Public awareness of education provides a today's modern economy, a highly skilled workforce is no longer needed because of rapid technological developments and increasingly simplified production processes. Thus, people with low education but trained will have the same relative productivity as people with high and formal education. This statement is formalized in a theory known as allocation theory or competition status that has the support of John Meyer [7] and Randall Collins [8]. One of the function of this allocation theory allocates personnel socially according to education strata who treat education as a social institution. People think if they want to get a higher status, then they must take higher education. Although those with higher education have a higher proportion of national income, an increase in the proportion of people with higher education in a nation will not automatically increase expansion or economic growth. Likewise, what happened in the Gili Genting islands, village heads sought various appropriate solutions to deal with the educational problems that exist in Gili Genting. Utilize scholarships provided by SANTOS to each village, and training courses for village officials. But those who already have a high education, not all return to their areas anymore. They prefer the city as a place to live and a place to work.

Most people's education in Gili Genting Island is elementary school and working as fishermen makes them lack of time to pay attention to educational problems, what they need is to get money to eat family meals at home. In addition, the environment also plays a role in improving the community's economy. Community intervention in improving the village economy is very much needed as with the existence of a tourism spot on Gili Genting the community able to open up small business land around the tourism site.

Hypothesis 3 which states that there is a positive and significant direct effect between tourism spots on improving economic is accepted. The direct effect of tourism spot on improving economic of 0.321 with a significance level of 0,000 or a probability smaller than 1 where this can be interpreted as having a significant general effect. 
According to Setyo and Ekoyudho, said that the increase in economic independence could be done through various efforts to strengthen the people's economy, increase capacity and expand the business sector for micro, small and medium enterprises, various training for young entrepreneurs, increase investment attractiveness, and the use of technology in order to improve the quality and quantity of production in the agriculture, industry and trade sectors and the optimization of regional tourism that has the potential to be developed, through community empowerment in areas with different potentials [9].

Improving the economy in the Gili Genting islands is arguably enough. This is due to the contribution of tourist attractions which are increasingly being known by domestic, local and international tourists. Pantai Sembilan is one of the best known by tourists. The existence of Pantai sembilan makes the economy of the surrounding area also increased, because it able to open jobs for the surrounding community. Seeing the potential of the Pantai Sembilan that are so large, the local government of Gili Genting is developing in order to improve the economy and this is in accordance with the government program namely "visit sumenep".

The indirect effect of public education on improving the economy through tourism spots was 0.166 while the direct effect of public education on improving the economy was 0.328 . The hypothesis which states that there is an indirect effect between public education on improving the economy through tourism spots is accepted. The indirect effect of public education on improving the economy through tourism spots by 0.494 shows that there is sufficient influence. The limitation of regional funds in the development of a village can affect the economic improvement of the community. For the people of Gili Genting who have higher education, it is not necessarily able to improve the economy in the area and vice versa it is not uncommon for those who have low education and economy but the community is able to increase the maximum economy, but public education is not necessarily one of the factors that influence the increase the economy, we need to know that many other factors that influence economic improvement are the support given by local governments in the form of tourism spot development. Provision of tourism spots in an area makes it easy for the community to increase the expected economy, this is very important for the community so that they can prosper the families in the area with the support of the local government so that poverty will decrease every year. The people of Gili Genting must be able to create creative ideas if they want tourism in the Gili Genting area to always attract local or long-distance tourists. So that regional income can continue to increase.

Public education will better affect the ranking of the economy directly than to affect the increase in the economy indirectly through tourism spot. The effect of public education on tourism spots is higher than the effect of tourism spots on improving the economy. High public education will ensure the development of tourism spots that are quite good, but another case with the effect of public education on Improving the economy. High public education does not necessarily increase the high economy and low public education may not necessarily result in a low economy. The effect of public education on tourism spots is only $26.6 \%$. It shows that the effect is very low and the remaining $73.4 \%$ is influenced by other variables such as community support, local government concern and so on. The effect of tourism spots on the improving economic of $10.3 \%$ shows that the effect is also very low and the remaining $89.7 \%$ such as strategies in promotion, motivation of local communities, public education, professionalism of local governments and so on. Public education able to play a role in improving the economy through tourism spots because the community is a social group that can change a condition for the better by increasing education and knowledge about the importance of developing an area for their economy.

Based on research results it can be seen that the increase in the economy is influenced by tourism spots and tourism spots are influenced by public education. This shows the importance of community education that provides support and their creative ideas for a better economic improvement.

\section{CONCLUSION}

Base on analysis result of data and discussion above, so the researcher can conclude as follow:(1) there are significant effects between public education on Tourism spot; (2) there are significant effects between public education on improving the economic;(3) there are significant direct effects between Tourism spot on improving the economic; (4) there are significant indirect effect between public education on improving economic through tourism spot. Direct effect is stronger than indirect effect. Direct effect was 0,328. While indirect effect was 0,166 . So that public education is higher to influence on improving economic directly than through on tourism spot as intervening variable.

\section{REFERENCES}

[1] S.W. Saraswati and H. Cahyono. "Pengaruh Tingkat Pendidikan dan Kesehatan terhadap PDRB Per Kapita di Kota Surabaya”.Jurnal Ilmiah, 2014.

[2] BPS Kabupaten Sumenep. "Kecamatan Gili Genting Dalam Angka 2018” BPS Kabupaten Sumenep.

[3] Nugroho. "Pengaruh Pendidikan Terhadap Pertumbuhan Ekonomi." Journal of Media Ekonomi Dan Manajemen, 29, 2, 2014.

[4] A.D. Foster and M.R. Rosenzweig. "Learning by Doing and Learning from Others : Human Capital and Technical Change in Aqriculture." The Journal of Political Economy, 103, 1176-1209, 1995.

[5] S. Arikunto, Prosedur Penelitian. Jakarta: Rineka Cipta, 2018. 2002.

[6] Riduwan and Engkos Achmad Kuncoro. Cara menggunakan dan memakai Analisis Jalur (Path Analysis). Bandung: Alfabeta, 2007.

[7] J.W. Meyer, "The Effect of Education as an Institution". America Journal of Sociology, 83, 55-77, 1977.

[8] R. Collins, The Credential Society. New York :Academic Press, pp. 191204, 1979.

[9] D.A. Setyo and A.N. Ekoyudho "Pengembangan Desa Bringsang Berdasarkan Aspek Ekonomi”, 2018. 